\title{
Influence of Pollen on the Development of Africanized Bee Colonies (Hymenoptera: Apidae)
}

by

\begin{abstract}
Anna Frida Hatsue Modro ${ }^{1 *}$, Luís Carlos Marchini ${ }^{2}$, Augusta Carolina de Camargo Carmello Moreti ${ }^{3} \&$ Emanuel Maia ${ }^{1}$
\end{abstract}

\section{ABSTRACT}

This study aimed to assess the importance of quality and quantity of pollen on the development of colonies in different seasons. The field experiment was conducted at the Apiary of the Department of Entomology and Acarology of Luiz de Queiroz College of Agriculture, using five beehives of $A$. mellifera. In order to characterize the quality of pollen, researchers considered measures of total dry mass $(\mathrm{g})$ and the physical-chemical and pollen composition of pollen load and bee bread samples. The development of hives was assessed according to the area covered by pollen, honey, and brood population in the hive $\left(\mathrm{cm}^{2}\right)$, as well as fluctuating asymmetry of worker bee wings. Spearman's correlation was calculated among the assessed parameters. The value of ether extract of pollen loads was the only component that was related to the development of hives, its value increased as the area occupied by pollen in the hive decreased $\left(-0.3200^{*}\right)$, and as the difference of the number of hamuli of right and left hind wings increased $\left(0.3317^{*}\right)$. There was a positive relationship between the wealth $\left(0.3150^{*}\right)$ and evenness $\left(0.3019^{*}\right)$ of pollen composition and the size of brood population inside the hive. It was concluded that the development of the colony, mainly considering the area occupied by brood, is more successful with increased quantity, wealth, and evenness of collected pollen.

Key words: Apis mellifera, fluctuating asymmetry, physical-chemical composition, bee nutrition, bee pollen.

\footnotetext{
${ }^{1}$ Universidade Federal de Rondônia, Departamento de Engenharia Florestal, Av. Norte Sul, 7300, Nova Morada, CEP 76940-000-Rolim de Moura, RO, Brazil

${ }^{2}$ EscolaSuperior de Agricultura 'Luiz de Queiroz', Departamento deEntomologia e Acarologia, Caixa Postal 9, CEP 13418-900-Piracicaba, SP, Brazil

${ }^{3}$ Secretaria de Agricultura e Abastecimento, APTA, Instituto de Zootecnia, Caixa Postal 60, CEP 13460-000- Nova Odessa, SP, Brazil

*Corresponding author: fridamodro@gmail.com.
} 


\section{INTRODUCTION}

Pollen is removed from the anthers of flowers and carried by the forager bees to the hive inside their corbicula or pollen baskets, located on the hind legs of the workers. The corbicula is surrounded by a fringe of hair into which pollen is placed to form the load (Michener 1974). Pollen loads, retained by collectors installed at the entrance of the hive or stored in honeycomb cells (bee bread), indicate period of production and botanical and geographical origins of the product (Vanderhuck 1995, Marques-Souza 1996, Carvalho et al. 1999).

Pollen is used in the feeding of larvae, and also adult bees, soon after their emergence until the beginning of the preparation of the synthesis of royal jelly for feeding the brood and the queen (Crailsheim 1992). It is known that the amount and composition of pollen can change the behavior of adult bees, fecundity, life span of bees, the size of the brood stock and honey, colony population, the development of bees, and larval food quality (Waller et al. 1981, Schmidt et al. 1987, Sagili et al. 2005, Toth et al. 2005, Hoover et al. 2006, Mattila \& Otis 2007, Human et al. 2007). It is noteworthy that Ioirich (1986) mentions that, in periods of protein resource shortage, and with no other source of protein, the colony may be extinct.

Considering the factors discussed above, this study aimed to assess the relevance of pollen quality for the development of Africanized bee (Apis mellifera) colonies in an area of Atlantic forest in the city of Piracicaba, SP.

\section{MATERIALS AND METHODS}

In order to characterize the quality of pollen, researchers considered as parameters: total dry mass ( $\mathrm{g}$ ), some nutritional components, and the plant origin of pollen load and bee bread samples. To assess the development of hives it was considered the size of the area covered by pollen, honey, and brood population in the hive, as well as fluctuating asymmetry of wings (module of difference between right and left wings) of active worker bees inside the hive. The field experiment was conducted at the Apiary of the Department of Entomology and Acarology of Luiz de Queiroz College of Agriculture, University of São Paulo, Piracicaba, São Paulo, where five beehives of $A$. mellifera (L.) were installed with a front pollen collector having mean retention rate of $45 \pm 1.19$ grains ( \pm mean standard error). 
Samples were collected in the fall (April 02, 2008 to May 28, 2008), winter (July 09, 2008 to Sept.03, 2008), spring (Oct.07, 2008 to Dec.02, 2008) and summer (Jan 09, 2009 to March 06, 2009), in a total period of 57 days for each season.

Pollen loads intercepted in the hives' entrances were collected every two days, cleaned by picking, and dried at $45^{\circ} \mathrm{C}$ for 48 hours as suggested by Funari et al. (1998a), the bee bread was collected every 15 days in a sorted manner within each hive. All samples were separated by fifteens and stored for further physical-chemical and pollen analyses.

Melissopalinological analysis of the samples was conducted with the use of acetolysis (Erdtman 1960) and the form of subsampling was recommended for the determination of the main pollen types occurring in a sample of heterospecific pollen (Modro et al.2009). The identification of pollen types was based mainly on reference collection of microscope slides from the Palynology Library of the Insects Laboratory at the Department of Entomology and acarology of the Luiz de Queiroz College of Agriculture, as well as specialized catalogs in pollen morphology of several species of plants. Approximately 900 pollen grains per sample were identified and counted.

The values of the physical-chemical composition, in samples of pollen loads and bee bread, were obtained from tests carried out according to Silva \& Queiroz (2002) in the Bromatology Laboratory of the Institute of Animal Science in Nova Odessa-SP. For pollen load samples, the percentage of dry matter, ether extract, mineral matter, crude protein, and total carbohydrates were measured. For the bee bread, percentages of dry matter and crude protein were determined. In samples with less than $2 \mathrm{~g}$, the value of dry matter was calculated from the other samples' mean moisture.

Within intervals of 15 days, during the collection period, the development of $A$. mellifera hives was assessed by measuring the area $\left(\mathrm{cm}^{2}\right)$ of brood, honey and pollen using the technique of Al-Tikrity et al. (1971).

Ten active worker bees inside each hive were collected every two weeks and fixed in $70 \%$ alcohol. Temporary measuring slides were mounted, where fore and hind, right and left wings were detached and rectilinearly placed between two histological slides. The following left and right hind wing morphological characters were measured, according to Silveira et al. (2002): radial subcostal vein, width and length of marginal cell, maximum total length and width 
of wing, length of cubital medial vein, length of cubital vein, length of anal vein, width of the 2 nd medial cell. The total number of hamuli of the right and left fore wings was counted. Measurements were made using a Leica stereomicroscope, containing an ocular micrometer, and the results were converted to millimeter units.

Spearman correlation was carried out among the areas occupied with brood, honey, and pollen, fluctuating asymmetry of wings, values of physical-chemical composition and diversity indexes ofShannon-Wiever $\left(\mathrm{H}^{\prime}\right)$, evenness expressed by Pielou (J') index, and Wealth, calculated by pollen composition. Statistical analyses were performed with the help of SAS statistical software (SAS Institute 2003) and the tests were applied to the 5\% level of probability.

\section{RESULTS AND DISCUSSION}

The largest area occupied with brood and honey was during the fall, and summer had the largest area with pollen (Table 1). Sequentially analyzing from the beginning offield assessments, one can observe a marked reduction in occupied area inside the hive between fall and winter, remaining low during spring with an increase in area of pollen in the summer. The occupation of a larger area with pollen in the summer associated with the availability of trophic resources are perhaps two of the factors responsible for increased area of brood and honey in the fall, based on a study conducted by Al-Tikrity et al. (1972).

The size of the bees showed similar absolute values among seasons, which confirms the results obtained by Herbert Jr. (1988) who found that nutritional stress did not influence the morphometric measurements of the bees, however, it is observed that the measures were slightly larger and more symmetrical in the fall (Table 2). Although the size of bees is a highly inheritable characteristic (Oldroyd et al. 1991), the size associated with greater measures of wind symmetry denote a more stable development of bees, whose subjects have bilateral symmetry. According to Woods et al. (1998), if the expression 
of a bilateral character is produced by the same genome, then any asymmetry of the sides is a result of environmental disturbance.

By comparing Table 1's data with those from Table 2 it is possible to observe that the fall was the season that had largest occupied area in the hive and also greater symmetry and size of bees. However, the summer, which was the season with the lowest and smallest area showed low levels of symmetry when compared to bees collected in other seasons, a characteristic

Table 2. Mean values of the asymmetry measurements and float to the morphological characteristics of Africanized bees (Apis mellifera), Piracicaba, SP, 2008-2009.

\begin{tabular}{|c|c|c|c|c|c|}
\hline \multirow[b]{2}{*}{ Characteristics } & & \multicolumn{4}{|c|}{ Season* ${ }^{*}$} \\
\hline & & Fall & Winter & Spring & Summer \\
\hline \multirow[t]{2}{*}{ Hamuli } & $\mathrm{N}^{(1)}$ & $21.59 \pm 0.112$ & $21.11 \pm 0.132$ & $21.18 \pm 0.132$ & $20.90 \pm 0.118$ \\
\hline & $\mathrm{A}^{(2)}$ & $1.179 \pm 0.071$ & $1.448 \pm 0.102$ & $1.256 \pm 0.074$ & $1.284 \pm 0.089$ \\
\hline \multirow[t]{2}{*}{ Total length } & $\mathrm{T}^{(3)}$ & $7.91 \pm 0.013$ & $7.88 \pm 0.014$ & $7.90 \pm 0.015$ & $7.86 \pm 0.013$ \\
\hline & A & $0.057 \pm 0.003$ & $0.059 \pm 0.004$ & $0.055 \pm 0.003$ & $0.058 \pm 0.004$ \\
\hline \multirow[t]{2}{*}{ Total width } & $\mathrm{T}$ & $2.91 \pm 0.006$ & $2.89 \pm 0.006$ & $2.88 \pm 0.008$ & $2.85 \pm 0.006$ \\
\hline & $\mathrm{A}$ & $0.038 \pm 0.002$ & $0.045 \pm 0.003$ & $0.044 \pm 0.003$ & $0.045 \pm 0.004$ \\
\hline \multirow[t]{2}{*}{ Radial subcostal vein } & $\mathrm{T}$ & $3.80 \pm 0.007$ & $3.78 \pm 0.009$ & $3.78 \pm 0.009$ & $3.78 \pm 0.009$ \\
\hline & A & $0.075 \pm 0.004$ & $0.094 \pm 0.006$ & $0.100 \pm 0.006$ & $0.087 \pm 0.006$ \\
\hline \multirow[t]{2}{*}{ Cubital medial vein } & $\mathrm{T}$ & $2.08 \pm 0.005$ & $2.06 \pm 0.005$ & $2.05 \pm 0.006$ & $2.05 \pm 0.006$ \\
\hline & $\mathrm{A}$ & $0.056 \pm 0.003$ & $0.055 \pm 0.003$ & $0.053 \pm 0.003$ & $0.047 \pm 0.003$ \\
\hline \multirow[t]{2}{*}{ Cubital vein } & $\mathrm{T}$ & $1.77 \pm 0.004$ & $1.78 \pm 0.004$ & $1.79 \pm 0.004$ & $1.78 \pm 0.004$ \\
\hline & A & $0.025 \pm 0.001$ & $0.025 \pm 0.001$ & $0.026 \pm 0.002$ & $0.023 \pm 0.001$ \\
\hline \multirow[t]{2}{*}{ Anal vein } & $\mathrm{T}$ & $3.88 \pm 0.007$ & $3.86 \pm 0.007$ & $3.86 \pm 0.008$ & $3.85 \pm 0.008$ \\
\hline & A & $0.040 \pm 0.002$ & $0.047 \pm 0.003$ & $0.043 \pm 0.003$ & $0.045 \pm 0.003$ \\
\hline \multirow[t]{2}{*}{ Length of marginal cell } & $\mathrm{T}$ & $2.97 \pm 0.007$ & $2.95 \pm 0.006$ & $2.96 \pm 0.006$ & $2.94 \pm 0.007$ \\
\hline & A & $0.036 \pm 0.002$ & $0.037 \pm 0.002$ & $0.034 \pm 0.002$ & $0.037 \pm 0.002$ \\
\hline \multirow[t]{2}{*}{ Width of marginal cell } & $\mathrm{T}$ & $0.45 \pm 0.002$ & $0.44 \pm 0.002$ & $0.44 \pm 0.002$ & $0.44 \pm 0.002$ \\
\hline & A & $0.028 \pm 0.001$ & $0.030 \pm 0.002$ & $0.028 \pm 0.002$ & $0.029 \pm 0.002$ \\
\hline \multirow[t]{2}{*}{ Width of 2 nd medial cell } & $\mathrm{T}$ & $0.81 \pm 0.002$ & $0.80 \pm 0.003$ & $0.80 \pm 0.003$ & $0.78 \pm 0.003$ \\
\hline & A & $0.027 \pm 0.001$ & $0.029 \pm 0.002$ & $0.030 \pm 0.002$ & $0.029 \pm 0.002$ \\
\hline
\end{tabular}

${ }^{(1)} \mathrm{N}$ : mean number of hamuli per wing, ${ }^{(2)} \mathrm{A}$ : fluctuating asymmetry calculated from the module difference among the measures of right and left wings, ${ }^{(3)} \mathrm{T}$ : total size of the characteristic, measured in millimeters ${ }^{*} \mathrm{Mean}$ \pm mean standard error. 
that denotes deviations from perfect symmetry of subjects with bilateral symmetry (Soulé 1979).

These results are strengthened by the assertion that, fluctuating asymmetry and size of subjects may reflect the instability development caused by stress, which in this study may be due to the amount of food available (Scheiner et al. 1991, Clarke 1995, Nosil \& Reimchen 2001, Kanegae \& Lomônaco 2003).

The area occupied with brood decreased with time of hive exposure to the pollen collector $\left(\mathrm{n}=45\right.$, $\mathrm{p}$-value $\left.<1 \% \mathrm{r}_{\mathrm{s}}=-0.38854\right)$. While Pereira $e t$ al. (2006), attributed the reproductive diapause in hives with collectors to environmental stress, discarding the nutritional factor, the same trend also presented for the areas of pollen and honey, in this study, seems to support the assertion that the use of collectors in Africanized bee hives interferes with the development of hives (McLellan 1974, Duff \& Furgala 1986a, 1986b, Shawer 1987, Funari et al. 1998b).

The value of ether extract of pollen loads was the only component that was related, significantly, with the development of hives, with greater value found with reduced area occupied with pollen in the hive, and with increased gap of the number of left and right hind wing hamuli (Table 3). Pollen with higher percentages of ether extract, when collected, may have been consumed more quickly than that with low percentages of such component, due to its phagostimulant function (Singh et al. 1999). Regarding the effect on hamuli fluctuation asymmetry, Parra (2007) mentions that the presence of linoleic acid, one of the essential fatty acids, is important in the formation of Anagasta kuehniella (Lepidotera) wings. However, this study cannot come to conclusions regarding the effect of ether extract composition on the development of bees (Table 3).

The larger the area of brood, the greater the amount of pollen collected by bees (Table 3) and the larger the area with pollen in the hive $(\mathrm{n}=45$, $\mathrm{p}$-value $\left.<1 \% r_{s}=0.4086\right)$. This result reinforces the hypothesis that the presence of brood in the hive (Pankiw et al. 1998, Dreller \& Tarpy 2000), as well as the lack of stored pollen (Hellmich \& Rothenbuhler 1986) stimulate forager bees to collect pollen. The pheromone of larvae or contact with the areas occupied by brood and stored pollen indicate the nutritional needs of the 
Table 3. Spearman correlation $(n=45)$ between the quality and quantity of pollen collected and the development of Africanized bee (Apis mellifera L.) hives, in Piracicaba, SP, 2008-2009.

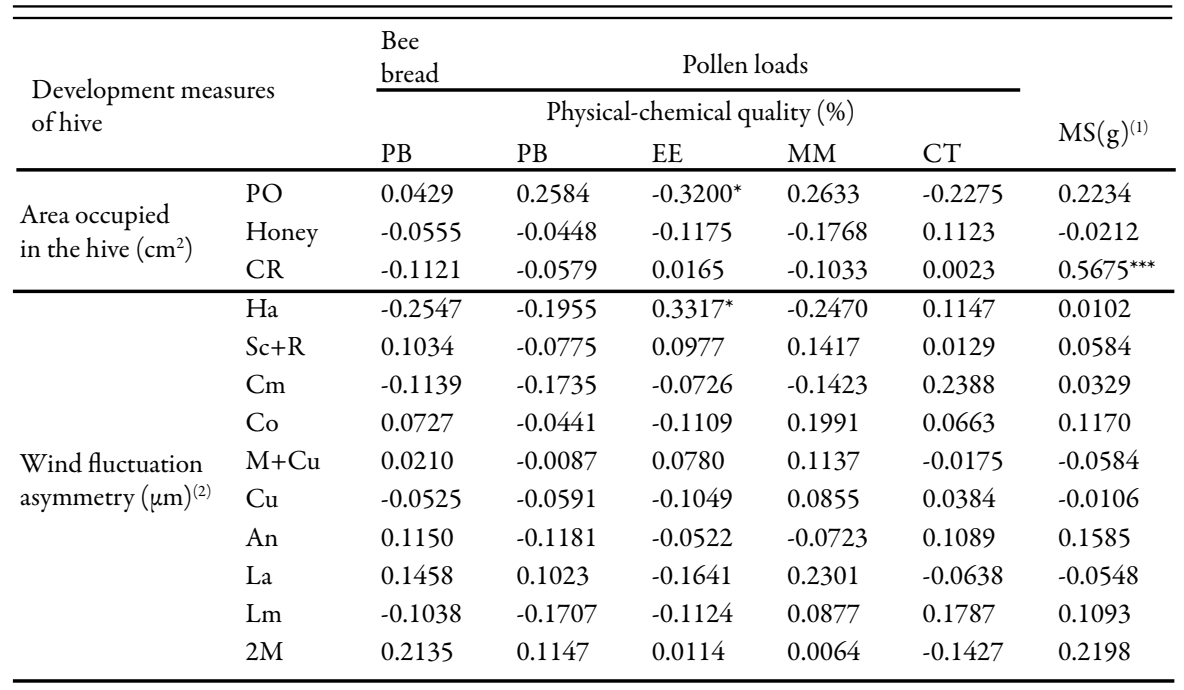

Notes:Pollen (PO), brood (CR), crude protein (PB), ether extract (EE), mineral matter (MM), total carbohydrates (CT) and dry matter (MS) ${ }^{(1)}$ Total amount of dry matter $(\mathrm{g})$ of pollen loads collected in a 15 -day period, ${ }^{(2)}$ fluctuating asymmetry in right and left hind wings, measure in micrometers $(\mu \mathrm{m})$ : radial subcostal vein $(\mathrm{Sc}+\mathrm{R})$, length of marginal cell $(\mathrm{Cm})$ total length of wing $(\mathrm{Co})$; cubital medial vein $(\mathrm{M}+\mathrm{Cu})$; cubital vein $(\mathrm{Cu})$; anal vein $(\mathrm{An})$, full width of the wing $(\mathrm{La})$, width of marginal cell $(\mathrm{Lm})$, width of the 2 nd medial cell $(2 \mathrm{M})$. Right and left fore wings: number of hamuli (HA), conventional signs used: ${ }^{*}$ Significant at $5 \%,{ }^{* * *}$ Significant at less than $0.01 \%$.

hive and determine foraging behavior of bees, for the collection of pollen or nectar, even in the case of Africanized bees.

The area occupied with honey however, was not associated with the area of pollen $\left(n=45\right.$, $p$-value $\left.>5 \% ; r_{s}=0.1882\right)$ nor with the area of brood $(n=$ 45 , $p$-value $\left.>5 \% r_{s}=0.0163\right)$, and that suggests that the search for sources of nectar occurs even in the absence of brood or with stored pollen, as proposed by Free (1967).

There was little relation between quality of pollen and development of the hive, which can be justified based on studies like the one conducted by Human et al. (2007), who noted the imbalance of the protein: carbohydrate ratio, which in the opinion of Schmidt (1985) would be more logical, in the case of a bee species that is extremely pollen oriented, in the use of resources and that feeds on pollen from a great diversity of plant species, so the cumulative effect of many compounds are responsible for the development and 
Table 4. Spearman coefficient $(n=56)$ between pollen composition and area occupied in hives by Africanized bees (A. mellifera) in Piracicaba, SP, 2008-2009.

\begin{tabular}{lllll}
\hline \hline \multirow{2}{*}{ Pollen composition } & & \multicolumn{3}{l}{ Area occupied in the hive $\left(\mathrm{cm}^{2}\right)$} \\
& & Pollen & Honey & Bee Springs \\
\hline Bee bread & Wealth & 0.2361 & 0.0408 & $0.3150^{*}$ \\
& Diversity & 0.0113 & -0.0686 & 0.2174 \\
\multirow{3}{*}{ Pollen loads } & Evenness & 0.0871 & -0.0831 & $0.3019^{*}$ \\
& Wealth & 0.0631 & -0.0347 & 0.2484 \\
& Diversity & -0.0187 & 0.0130 & 0.0682 \\
& Evenness & -0.0149 & 0.0286 & 0.0068 \\
\hline
\end{tabular}

Conventional signs used: *Significant at $5 \%$.

behavior of bees, and not some specific compounds, which usually occurs in monophagous species. In accordance with this assertion, Table 4 shows a positive relationship between wealth and evenness of pollen composition and the size of the area occupied by brood in the hive.

Although some studies show that the nutritional quality of pollen may determine the amount to be collected in foraging behavior, with an influential evoluting factor in food preference of bees, according to the needs of the hive (Pernal \& Currie 2001, 2002), in this work, the amount of intercepted pollen in traps did not relate to its physical and chemical quality $(\mathrm{n}=45$, $\mathrm{p}$-value> 5\%). Free (1967) and Sagili \& Pankiw (2007) also found no relationship between the amount of pollen collected and its values of carbohydrates and crude protein, respectively.

\section{CONCLUSIONS}

Brood and honey occupied a largest area in hives during the fall, and summer had the largest area with pollen.

The size of bees did not vary significantly among seasons.

The development of the colony, measured primarily by the size of the area occupied with brood, is more successful with increased amount of pollen collected, wealth, and evenness of pollen composition and less successful with increased time of exposure to pollen collectors.

The amount of pollen intercepted in traps shows no relationship to its physical and chemical quality. 


\section{ACKNOWLEDGMENTS}

\section{The authors thank CNPq, CAPES and FAPESP for the financial support for conduction of the Project and scholarships.}

\section{REFERENCES}

Al-Tikrity, W.S., R.C.Hillmann, A.W.Benton \&W.W.Charke-Júnior 1971. A new instrument for brood measurement in a honey-bee colony. American Bee Journal 111(1):20-26.

Al-Tikrity, W.S., A.W.Benton, R.C.Hillmann \& W.W. Charke-Júnior 1972. The relationship between the amount of unsealed brood in honeybee colonies and their pollen collection. Journal of Apicultural Research 11(1):9-12.

Carvalho, C.A.L., L.C. Marchini \& P.B. Ros 1999. Fontes de pólen utilizados por Apis mellifera L. e algumas espécies de Trigonini (Apidae) em Piracicaba (SP). Bragantia 58(1):49-56.

Clarke, G.M. 1995. Relationship between developmental stability and fitness: application for conservation biology. Conservation Biology 9:18-24.

Crailsheim, K. 1992. The flow of jelly within a honey bee colony. Journal of comparative physiology B 162:681-689.

Dreller, C. \& D.R. Tarpy 2000. Perception of the pollen need by foragers in a honeybee colony. Animal behaviour 59:91-96.

Duff, S.R. \& B. Furgala 1986a. Pollen trapping honey bee colonies in Minnesota. Part I: Effect on amount of trapped, brood, reared, winter survival, queen longevity, and adult bee population. American Bee Journal 126(10):686-689.

Duff, S.R. \& B. Furgala 1986b. Pollen trapping honey bee colonies in Minnesota. Part II: Effect on foraging activity, honey production, honey moisture content, and nitrogen content of adult workers. American Bee Journal 126(11):755-758.

Erdtman, G. 1960. The acetolysis method. A revised description. Svensk Botanisk Tidskrift 39:561-564.

Free, J.B. 1967. Factors determining the collection of pollen by honeybee foragers. Animal behaviour 15:134-144.

Funari, S.R.C., H.C. da Rocha, J.M. Sforcin \& P.R. Curi 1998a. Número de bactérias em função do método de secagem do pólen. In: Reunião Anual da Sociedade Brasileira de Zootecnia, 35, 1998. Anais... Botucatu/SP: Sociedade Brasileira de Zootecnia, p. 525-527.

Funari,S.R.C.,H.C. da Rocha \& J.M.Sforcin 1998b. Pollen collection and colony development of africaized honeybees (Apis mellifera L.). In: Reunião Anual da Sociedade Brasileira de Zootecnia, 35, 1998. Anais... Botucatu/SP: Sociedade Brasileira de Zootecnia, p. 525-527.

Hellmich, R.L. \& W.C. Rothenbuhler 1986. Pollen hoarding and use by high and low pollen-hoarding honeybees during the course of brood rearing. Journal of Apicultural Research 25(1):30-34. 
Herbert Júnior., E.W. 1988. Influence of nutritional stress and the age of adults on the morphometrics of honey bees (Apis mellifera L.). Apidologie 19(3):221-230.

Hoover, S.E.R., H.A. Higo \& M.L. Winston 2006. Worker honey bee ovary development: seasonal variation and the influence of larval and adult nutrition. Journal of Comparative Physiology, B: Biochemical, Systematic, and Environmental Physiology 176:55-63.

Human, H., S.W. Nicolson, K. Strauss, C.W. Pirk \& V. Dietemann 2007. Influence of pollen quality on ovarian development in honeybee workers (Apis mellifera scutellata). Journal of Insect Physiology 53:649-655.

Ioirich, N.P. 1986. As abelhas, farmacêuticas com asas. Moscovo, Mir.

Kanegae, A.P. \& C. Lomônaco 2003. Plasticidade morfológica, reprodutiva e assimetria flutuantede Myzuspersicae (Sulzer) (Hemiptera: Aphididae) sob diferentes temperaturas. Neotropical entomology 32(1):37-43.

Marques-Souza, A.C. 1996. Fontes de pollen exploradas por Melipona compressipes manaosensis (Apidae: Meliponinae), abelha da Amazônia Central. Acta Amazônica 26(1-2):77-86.

Mattila, H.R. \& G.W. Otis 2007. Dwindling pollen resources trigger the transition to broodless populations of long-lived honeybees each autumn. Ecological Entomology 32:496-505.

Mclellan, A.R. 1974. Some effects of pollen traps on colonies of honeybees. Journal of Apicultural Research 13(2):143-148.

Michener, C.D. 1974. The social behaviour of the bees. Cambridge, Havard University Press.

Modro, A.F.H., E. Maia, I.C. da Silva, C.F.P. da Luz \& D. Message 2009. Subamostragem de pólen apícola para análise melissopalinológica. Hoehnea 36(4):709-714.

Nosil, P. \& T.E. Reimchen 2001. Tarsal asymmetry, nutritional condition, and survival in water boatmen (Callicorixa vulnerata). Evolution 55(4):712-720.

Oldroyd, B., T. Rinderer \& S. Buco 1991. Heritability of morphological characters used to distinguish European and Africanized honeybees. Theoretical and applied genetics 82:499-504.

Pankiw, T., R.E. Page Júnior. \& M.K. Fondrk 1998. Brood pheromone stimulates pollen foraging in honey bees (Apis mellifera). Behavioral Ecology and Sociobiology 44:193198.

Parra, J.R.P. 2007. Técnicas de criação de insetos para programas de controle biológico. Piracicaba, ESALQ/FEALQ.

Pernal, S.F. \& R.W. Currie 2001. The influence of pollen quality on foraging behavior in honeybees (Apis mellifera L.). Behavioral Ecology and Sociobiology 51:53-68.

Pernal, S.F. \& R.W. Currie 2002. Discrimination and preferences for pollen-based cues by foraging honeybees, Apis mellifera L. Animal Behaviour 63:369-390.

Pereira, F. de M., B.M. Freitas, J.M. Vieira Neto, M.T. do R. Lopes, A. de L. Barbosa \& R.C.R. de Camargo 2006. Desenvolvimento de colônias de abelhas com diferentes alimentos protéicos. Pesquisa agropecuária brasileira 41(1):1-7. 
Sagili, R.R. \& T. Pankiw 2007. Effects of protein-constrained brood food on honey bee (Apis mellifera L.) pollen foraging and colony growth. Behavioral Ecology and Sociobiology 61:1471-1478.

Sagili, R.R., T. Pankiw \& K. Zhu-Salzman 2005. Effects of soybean trypsin inhibitor on hypopharyngeal gland protein content, total midgut protease activity and survival of the honey bee (Apis mellifera L.). Journal of Insect Physiology 51:953-957.

SAS INSTITUTE, 2003. SAS user's guide statistics. Cary, USA.

Scheiner, S.M., R.L. Caplan \& R.F. Lyman 1991. The genetics of phenotypic plasticity. III. Genetic correlations and fluctuanting asymmetries. Journal of evolutionary biology 4:51-68.

Schmidt, J.O. 1985. Phagostimulants in pollen. Journal of Apicultural Research 24(2):107114.

Schmidt, J.O., S.C. Thoenes \& M.D. Levin 1987. Survival of honey bees, Apis mellifera (Hymenoptera: Apidae), fed various pollen sources. Annals of the Entomological Society of America 80 (2):176-183.

Shawer, M.B. 1987. Major pollen sources in kafr el-sheikh, Egypt, and the effect of pollen supply on brood area and honey yield. Journal of Apicultural Research 26(1):43-46.

Silva, D.J. \& A.C. de Queiroz 2002. Análises de Alimentos, Métodos Químicos e Biológicos, Editora Universidade Federal de Viçosa, Viçosa, MG.

Silveira, F.A., G.A.R. Melo \& E.A.B. Almeida 2002. Abelhas Brasileiras: sistemática e identificação. Fernando A. Silveira, Belo Horizonte, MG.

Singh, S., K. Saini \& K.L. Jain 1999. Quantitative comparison of lipids in some pollens and their phagostimulatory effects in honeybees. Journal of apicultural research 38(12):87-92.

Soulé, M.E. 1979. Heterozygosity and developmental stability another look. Evolution 33(1):396-401.

Toth, A.L., S. Kantarovich, A.F. Meisel \& G.E. Robinson 2005. Nutritional status influences socially regulated foraging ontogeny in honey bees. The Journal of Experimental Biology 208:4641-4649.

Vanderhuck, M.G. 1995. Analisis palinologico de la mile y la carga de pollen colectada por Apis mellifera em el suroeste de Antioquia, Colômbia. Boletim Museu Entomologia Universidad del Valle 3(2):35-54.

Waller, G.D., D.M. Caron \& G.M. Loper 1981. Pollen patties maintain brood rearing when pollen is trapped from honey bee colonies. American Bee Journal 121(2):101-105.

Woods, R.E., M.J. Hercus \& A.A. Hoffmann 1998. Estimating the heritability of fluctuating asymmetry in field Drosophila. Evolution 52(3):816-824. 
